\title{
남성패션잡지에 나타난 외모의 변화양상
}

\section{The Changing Aspect of Appearances in Male Fashion Magazines}

\author{
박수진 · 박길순* \\ 충남대학교 의류학과 시간강사·충남대학교 의류학과 교수 \\ Su-Jin Park $\cdot$ Kil-Soon Park \\ Chungnam National University Dept. of Clothing\& Textile a Part-Time Lecturer • \\ Chungnam National University Dept. of Clothing\& Textile Professor
}

\begin{abstract}
This study aims on observing the social recognition and its aspects for men taking care of their outer appearances at current point where men are rapidly rising as the main consumer in the beauty industry while their interest for outer appearances are increasing. Therefore, we observed the overall trend and changes in social recognition for male looks by analyzing the contents of articles in fashion magazines that play the critical role of spreading the trend while suggesting and delivering the diverse trend changes to the public to correspond to the individual and concrete demands of certain class segmented into gender, age, hobby, and more. As a result, articles related to outer appearances were divided into fashion, cosmetic and skin, hair and scalp, body figure care, cosmetic surgery, and others, and among them, fashion category took up the highest ratio. Also, articles related to outer appearances increased even more according to the change in time, where articles related to fashion and hair increased while articles of other categories decreased.
\end{abstract}

Key Words : Appearance Management, Fashion Magazines, contents Analysis

\section{I . 서론}

\section{1. 연구의 필요성}

아름다움이나 이상적인 미에 대한 사람들의 생각은 그 시대의 사회적, 경제적, 문화적인 환경의 변화에 따라 변 화되어 왔으며 남성보다는 여성의 아름다움이나 이상적인 미가 더욱 부각되어 왔다. 그러나 남녀의 역할 구분이 모 호해지고 각 분야에서 성의 구분없이 자신의 역량을 발휘 하게 되면서 아름다움이나 미에 대한 관심 또한 성별에 따른 차이가 사라지게 되었다. 또한 경제가 꾸준히 성장 하고 삶의 여유가 생기면서 남성들은 레저나 여행 등 야 외활동을 비롯하여 패션이나 뷰티 등 외모관리에 관심을 가지기 시작하였다. 패션에 대한 관심에서 시작된 남성의 외모관리는 피부, 헤어스타일, 몸매, 성형 등 다양한 분야
로 확산되고 있으며 남성관련 패션 및 뷰티산업은 꾸준히 성장세를 보이고 있다. 이러한 남성의 변화를 바라보는 사회적인 시각 또한 변화하여 과거에는 직업적인 능력만 이 남성을 평가하는 기준이었으나 직업적인 능력과 더불 어 외모적인 측면도 그 사람의 역량을 평가하는 중요한 요인으로 작용하게 되었다. 이러한 현상은 청소년 세대인 10 대부터 40,50 대인 중장년 세대, 60 대 이상의 노년층까 지 전 연령대에서 다양한 양상으로 나타나고 있는데 각 세대별로 관심의 정도나 경향에는 차이가 있으나 패션이 나 뷰티에 대한 관심은 급격히 증가하였다. 이러한 남성 들의 변화는 가장 가시적이라 할 수 있는 패션에서 시작 되어 헤어스타일 및 피부 등 뷰티관련으로 확산되었으며, 건강과도 결부되면서 몸매관리도 중요한 관심사로 부상하 였다. 또한 가장 손쉽게 변화될 수 있는 방법으로 성형도 부각되기 시작하였는데 점이나 잡티를 제거하는 간단한 시술에서 코 융비술이나 쌍꺼플과 같이 다소 복잡한 시술

* Corresponding author: 저자각주 넣어주세요.

Tel: 042) 821-6826, Fax: 000) 000-00004

E-mail: kspark@cnu.ac.kr 
까지 시술을 받는 정도가 다양해지고 있다. 이에 따라 남 성만을 대상으로 하는 전문샵의 형태가 증가하고 있으며, 남성들이 패션 및 뷰티산업에서 중요한 소비자로 급부상 하고 있다. 이러한 남성의 변화 및 남성외모 관련시장의 변화에 대응하기 위해서는 남성외모에 대한 인식의 변화 및 변화양상을 살펴보는 것이 필요하다고 생각된다. 따라 서 본 연구는 남성패션잡지의 기사 변화를 통해 외모나 외모관리에 대한 남성들의 인식이 어떻게 변화되어왔으며 어떠한 양상을 보였는지 살펴보고자 한다.

\section{2. 연구 목적}

남성들의 외모에 대한 관심이 전 연령층에 걸쳐 보편 적으로 증가함에 따라 인터넷 쇼핑몰과 같은 온라인 샵은 물론이고 고객과 직접 접촉하는 오프라인의 매장까지 남 성만을 위한 매장이 개설되고 있으며, 남성관련 뷰티 산 업에 있어서는 그 성장세가 꾸준히 증가하고 있는 실정이 다. 패션에 있어서는 과거와 달리 여성과 같이 다양한 스 타일이 공존하고 있으며, 남성전용 피부관리실이 개설되 고, 피부특성별로 기능별로 세분화되고 전문화된 남성전 용 화장품이 출시되고 있다. 염색이나 펌을 한 남성의 모 습은 자연스러운 현상으로 받아들여지고 있으며, 우리나 라 남성의 전형적인 헤어스타일이라고 할 수 있는 스포츠 형의 헤어스타일에서 벗어나 자신의 취향에 따라 다양한 길이와 스타일로 연출되고 있다. 또한 건강관리과 더불어 계절의 변화나 사회적 상황에 따른 몸매 만들기가 남성들 사이에서 유행을 하고 있다. 이와 같이 남성들의 외모에 대한 관심의 증가 및 주도적인 소비자로서의 부상에 따라 남성의 외모관리행동과 관련된 연구들이 진행되고 있으나 전반적으로 남성들의 외모에 대한 인식의 변화나 그 변화 양상을 고찰한 연구는 부족한 실정이다.

한편, 잡지는 보다 다양화되고 전문화된 독자의 욕구를 가장 정확하게 수용할 수 있는 전문정보매체이자, 정보 지식사회의 기간산업으로 중요한 역할을 담당하는 측면이 강한 매체라고 할 수 있다. 또한 인터넷의 발달로 인터넷 잡지 및 웹진의 발행이 증가하면서 직접 구입하여 구독하 던 과거보다 좀 더 쉽게 접근할 수 있고 편안하게 구독할 수 있게 되어 그 미래에 대한 전망이 밝다고 할 수 있다. 이와 같이 잡지는 독자의 욕구를 수용하여 편집되는 특성 이 있는 것이므로 남성을 대상으로 한 남성잡지의 기사 내용 및 그 변화양상을 통해 남성들의 관심이나 취향, 특
성을 알아볼 수 있으며, 태도나 인식이 어떻게 변화되었 는지 살펴볼 수 있으리라 생각된다.

따라서 본 연구에서는 남성을 대상으로 라이프스타일 및 패션, 피부, 헤어스타일, 몸매관리 등을 다루고 있는 남성잡지의 기사내용을 분석하여 남성들의 외모관리에 대 한 인식 및 그 변화양상을 고찰하고자 한다. 구체적인 목 적은 다음과 같다.

1) 남성외모관련 기사의 주제유목별 분포 양상을 고찰 하고자 한다.

2) 남성외모관련 기사의 주제유목별 내용을 분석하고자 한다.

3) 연도별, 시대별 남성외모관련 기사 비율의 변화양상 을 고찰하고자 한다.

\section{ㅍ. 잡지 및 패션잡지의 이해}

\section{1. 잡지의 개념 및 특성}

일간을 제외한 일정한 시간적 간격을 두고 규칙적으로 발간되는 간행물을 일컫는 잡지(Magazine)의 어원은 많은 것을 쌓아 두는 '창고'라는 의미를 가진 프랑스어 마가쟁 (magasin)이다. 이선영(2001)은 '잡지는 여러 가지 지식을 많이 갖추어 기록한 것'이라고 볼 수 있다고 하였으며1), 미국의 신문사 연구가인 프랭크 모트는 잡지를 ‘다양한 읽을거리를 포함한 대체로 정기적으로 간행되는 제본된 출판물'이라 정의하였고, 윌슬리는 '일반 독서대중을 대상 으로 한 기사-소설·시·사진 등의 잡다한 내용이나 또 는 특정한 취미, 관심이나 직업을 가진 집단 및 특정한 연 령집단을 대상으로 한 특수 내용을 포함한 정기 간행물' 이라고 정의하였다2).

우리나라에서는 현행 정기간행물법 제2조 8 항에 따라 ‘잡지라 함은 정치, 경제, 사회, 문화, 시사, 산업, 과학, 종 교, 교육, 체육 등 전 분야 또는 특정분야에 관한 보도, 논 평, 여론, 등의 정보를 전파하기 위해 동일한 제호로 월 1 회 이하 정기적으로 발행하는 제책된 간행물을 말한다'고 정의하고 있다.

잡지는 흔히 제 3 의 언론으로 일컬어지며, 일반적으로 신문과 방송보다 시사전달의 보도와 논평에 있어 뒤떨어 지는 것으로 간주되고 있으나, 고도의 지적 정보 전달 등 의 전문성에서는 더욱 앞선다고 보고 있다. 이에 이재호

1) 이선영, 해외매체의 국내수용 현황 -라이선스 잡지와 외국 영어매체를 중심으로-, (서울: 커뮤니케이션북스, 2001), p.43.

2) 이정춘, 현대사회와 매스미디어. (서울: 나남, 1990), p.136. 
(2001)는 잡지는 신문에 비해 전문화되고 분석적인 정보 를 제공하고 도서에 비해 신속한 정보전달이 가능하며, 사회 여론 형성 및 문화정체성을 형성하는 기능을 수행하 는 매체라 할 수 있다고 하였다3). 그러므로 잡지의 내용 은 교육적이고 문학적이며 예술성과 학술성을 띠고 있어 수용자들에게 오랫동안 영향을 미치며, 그 강도와 심도가 신문과 방송보다 훨씬 강한 것으로 인식되고 있다.

따라서 이선영(2001)은 잡지는 방송이나 신문과 같은 신속성은 부족하지만 사건의 흐름을 다루는 데는 시간적 여유가 있어서 분석에 유리하며, 적시성과 계속성에 있어 서는 서적과 구별된다고 하였다4). 또한 자신의 욕구나 필 요를 명확히 할 수 있는 정보추구 동기를 만족시키며, 사 회적 관계의 동기와 요구를 수용할 수 있는 간접적인 대 화의 수단으로 이용되어진다. 따라서 잡지분야는 지식정 보 및 문화산업으로서 정보화시대의 근간산업으로서 문화 적 파급력이 높은 분야이며, 다양한 전문지의 출간은 문 화의 다양성과 계층 간의 다원성적인 발전에 도움을 줄 수 있는 강력한 매체라 할 수 있다. 또한 잡지는 복잡하고 어려운 현실보다는 부담없이 즐길 수 있는 취미, 오락, 소 설이나 수필을 접할 수 있는 오락적인 측면을 가져 더욱 손쉽게 읽혀진다고 할 수 있다.

전영표(1997)는 위와 같은 측면에서 잡지는 언론출판과 함께 한 나라 국민의 정신세계를 좌우하는 중요한 받침대 라 할 수 있다고 하였으며5), 따라서 서정우(1990)는 잡지 저널리즘의 기능은 보도의 기능, 지도의 기능, 오락의 기 능, 광고의 기능을 가지고 있다고 하였다6).

\section{2. 패션잡지와 에스콰이어}

잡지는 패션미디어로서 적합한 여러 성격을 지니고 있 다고 할 수 있는데 우선 잡지는 대체로 전국적으로 배포 된다는 점과 다른 인쇄매체에 비하여 색채인쇄결과가 좋 아 독자의 주의를 끌 수 있다. 또한 전문성을 이용하면 최 소의 소비부수로서 특정한 독자층에 정보를 효율적으로 전달할 수 있으며, 다른 매체에 비해 비교적 마음의 여유
를 가지고 읽게 되므로 긴 설명을 해야 하는 광고주에게 는 유리하다. 또한 잡지는 매체수명 즉, 매체와 독자 간에 접촉기간이 길고 보존율이 높은 편이어서 한번 읽고 버리 는 것이 아니라 대여되는 방법으로 발행부수보다 많은 독 자에게 읽혀지는 특성도 가진다. 특히 이희남(1988)은 잡 지는 기사들이 전문인들에 의하여 쓰여지므로 정보에 대 하여 신뢰와 권위, 설득력을 갖게 되며, 편집진의 정리된 언급은 소비자의 인식을 높여 주는데 기여한다고 하였 다7).

윤을요(1997)는 패션잡지는 일반잡지가 문자라는 기호 를 통하여 독자에게 정보를 전달하는 것과는 달리 기사와 함께 화보하는 시각적 지면을 이용하여 보다 더 효과적으 로 그 내용을 전달해준다는 장점이 있다고 하였다8). 즉, 화보가 정보전달의 보조수단으로 이용되는 일반잡지와 달 리 화보가 주체적인 목적으로 사용되는 패션잡지는 그 용 도 면에서 커다란 차이를 지니고 있으며, 이러한 차이점은 곧 패션잡지만이 가지는 특징이 된다는 것이다9). 따라서 패션잡지는 같은 시간에 공간적으로 분산되어 있는 이들 에게 공통의 감각을 소유하도록 하며, 최신의 정보로서 인 지하게 하는 기능을 담당해왔다. 그러나 패션잡지라도 패 션기사만을 게재하는 것이 아니라 전체 기사분량 중 가장 큰 비중을 차지하는 것이 패션기사라는 것이며, 일반적으 로 패션기사, 뷰티(미용, 헬스)기사, 피처(인터뷰, 문화, 리 포트, 칼럼 등) 등으로 구성되어 있다. 어떤 종류의 기사를 더욱 부각시키는냐에 따라 잡지의 개성이 달라지며, 독자 와 광고주는 이에 따라 선호 잡지를 선택하게 된다.

염혜정(2000)은 최근에는 현대 패션이 단순히 산업이 아닌 생활문화 산업으로 전환되면서 패션잡지는 최신 유 행을 전달하는 것 뿐 아니라 입고, 먹고, 즐기는 모든 것 을 포함한 라이프스타일을 창조하고 제안한다는 점에서 그 역할은 날로 확대, 중시되고 있다고 하였다10). 따라서 김현주(2006)는 패션잡지는 정확한 패션정보를 전달해야 하며, 패션의 질적 향상이 삶의 질적 향상에 실질적인 영 향을 행사한다는 것을 알아야 하고, 그러기 위해 독자에 게 문화적 자극제가 되어야 한다고 하였다11).

국내에서는 1968년에 발간된 '의상’과 1984년에 ‘월간

\footnotetext{
3) 이재호, 대중매체와 사회, (서울: 도서출판 양지, 2001), p.171.

4) 이선영, op. cit., p.44.

5) 전영표, 출판문화와 잡지 저널리즘, (서울: 대광문화사, 1997), ibid, 이선영 재인용

6) 서정우, 잡지언론의 사명, 잡지발전 세미나 자료집, 한국잡지협회, $1990 \mathrm{ibid}$, 이재호 재인용

7) 이희남, "패션미디어로서의 패션잡지에 대한 고찰", 상지대 논문집, 9권, (1988), p.102.

8) 윤을요, "국내 라이선스 패션잡지의 현황과 개선방안에 관한 연구", (국민대학교 대학원 석사학위논문, 1997), p.3.

9) 윤을요, ibid, pp. 24 25.

10) 염혜정, "일본의 패션잡지에 나타난 스트리트 패션 스타일-1960년대 1990년대를 중심으로-", 한국의류학회지, 50권 6호, (2000), pp.74 75.

11) 김현주, "2000년이후 패션잡지의 적응저널리즘에 관한 연구", (연세대학교 언론홍보대학원 석사학위논문, 2006), p.12.
} 
멋'이 패션전문잡지로 출간되다가 폐간이 된 후 패션정보 만을 다루는 잡지보다는 종합지나 분야별로 전문화된 잡 지가 출간되었다. 그러나 1990년대 이후에 외국의 라이선 스 잡지들이 본격적으로 진입하면서 세계적인 브랜드를 앞세우고 양질의 기사와 사진 등을 통해 독자들에게 국제 트렌드를 소개하고 있는데 패션잡지의 경우 주로 여성잡 지가 대부분이지만 남성의 패션, 라이프스타일을 제시하 는 남성잡지도 출간되기 시작하였다.

남성잡지 중 '에스콰이어(Esquire)'는 미국의 가장 대표 적인 교양문예지로 미국의 대표적인 남성잡지이며, 생활 과 레저의 예술을 구가하는 것을 목표로 하고 있어 패션, 뷰티, 스포츠에 이르는 다양한 내용을 담고 있다. 국내에 는 1995년 9월에 처음 발행되기 시작하였는데 국내 최초 로 더맨(The Man), 힘(Him), 지지(G\&G)와 함께 남성지 시장을 열었으나 현재까지 출간되는 것으로는 유일한 잡 지이다. 2000년 이후에는 지큐(GQ), 아레나(Arena) 등이 출간되어 남성패션 및 라이프스타일잡지 시장은 확대되고 있는 추세이다.

에스콰이어 한국판은 한국 남성의 필요와 정서에 맞고 그들의 관심을 끌 만한 주제를 가지고 로컬기사를 많이 제작하고 있는데 잡지의 앞부분에서는 최고의 남자나 경 제기사, 인터뷰 등을 게재하고 있고, 중간부분에는 새로운 과학기술이나 항공기, 자동차 등에 대한 정보 및 여향관 련 기사들을 싣고 있다. 또한 남성들의 속성에 대한 리포 트 및 여성들의 심리를 살펴볼 수 있는 기획기사도 게재 하고 있다. 잡지 후반부는 패션관련 내용이나 상품 소개 란 등으로 구성되어 있으며, 특히 '가이드'나 '스타일업' 등의 항목이나 '아이템 코디네이션'에서는 코디네이션에 도움이 되는 정보들을 제공하고 있다. 패션화보의 경우, 발행초기에는 사진기술이 부족하고 기획력이 부족하여 외 국 기사 또는 화보를 그대로 게재하는 경우가 많았으나 최근에는 향상된 사진술 및 구성력으로 패션화보나 각종 기획물을 국내에서 기획하고 제작하고 있었다.

위에서 살펴본 바와 같이, 패션잡지는 사회의 변화에 가장 민감한 잡지라 할 수 있으며, 전문적인 정보와 시각 정보를 통해 소비자의 인식을 높여주는데 기여한다고 할 수 있다.

따라서, 본 연구에서는 남성의 문화를 대변한다고 할 수 있는 남성패션라이프스타일잡지인 에스콰이어의 외모
관련기사를 내용 분석하여 남성들의 외모에 대한 인식 및 그 변화양상을 살펴보고자 한다.

\section{III. 연구방법}

\section{1. 연구의 대상 및 자료선정}

본 연구에서는 남성의 외모관리에 대한 인식 및 외모 관리행동의 변화양상을 살펴보기 위해 특정한 취미나 관 심을 가진 집단을 대상으로 하여 그에 맞는 정보를 제공 하며 독자들의 욕구를 수용하여 출간되는 특성을 가진 남 성잡지의 기사를 연구의 대상으로 선정하였다.

분석 자료로는 남성을 대상으로 한 남성패션라이프스 타일잡지인「에스콰이어」의 외모관련 기사로 선정하였 다.「에스콰이어」는 미국에서 1933년 창간된 이래로 우 리나라를 포함한 세계 12 개국에서 발간되어 남성의 라이 프스타일에 지대한 영향을 끼쳐 왔으며, 우리나라 최초로 발간된 남성전문 패션교양잡지로 1990년 중반에 라이선스 잡지의 창간이 붐을 일기 시작했을 때부터 출간되기 시작 하여 시대의 변화에 따른 변화양상을 살펴 볼 수 있어 분 석자료로 선정되었다. 연구의 시기는 시대에 따른 변화양 상을 살펴보기 위해 에스콰이어의 창간 초기인 1996년부 터 2005년까지 10년으로 정하였으며, 에스콰이어는 월간 으로 출간되므로 총 120 권이 분석자료로 사용되었다.

\section{2. 분석유목의 선정}

본 연구에서는 남성 외모관련 기사를 내용분석하기 위 해 김은주(2001)12), 최지성(2002)13), 문지영(2003)14), 정규 진(2004)15), 김선희(2003)16), 박지현(2002)17) 등의 연구를 참고하여 외모 및 외모관련 기사의 주제유목을 패션, 헤 어 및 두피, 화장품 및 피부, 몸매관리, 성형으로 선정한 후 성형을 제외한 각 유목은 다시 하위영역으로 나누어 분석하였으며 그 외에 기타유목을 추가하여 위의 5 유목 중 하나로 명확히 분류될 수 없거나 패션, 화장품, 헤어스 타일 등 모든 영역의 내용을 포함하고 있는 기사는 분류

12) 김은주, "여대생의 외모관리행동에 관한 연구", (이화여자대학교 대학원 석사학위논문, 2001).

13) 최지성, "남성의 외모관리에 대한 태도 연구", (연세대학교 대학원 석사학위논문, 2002).

14) 문지영 - 김정원, "20대 남성의 이미지 추구에 관한 연구", 한국의류산업학회지, 6권 6호, (2004), pp.715 722.

15) 정규진, "자기표현과 외모관리행동 및 신체노출 관련연구", (연세대학교 대학원 석사학위논문, 2004).

16) 김선희, "외모에 대한 사회문화적 태도와 외모관리행동에 대한 연구". 대한가정학회지, 41권 5호, (2003) pp.99 108

17) 박지현. “현대 한국사회의 '몸관리'유행의 사회학적 의미”. (부산대학교 대학원 석사학위논문, 2002). 
하여 분석하였다. 패션유목은 트렌드 관련, 코디네이션 및 연출방법관련, 액세서리관련, 패션화보, 광고성, 기타의 하 위영역으로, 화장품 및 피부유목은 케어 및 화이트닝관련, 태닝 및 향수관련, 신체 및 면도관련, 광고성, 기타의 하 위영역으로, 헤어 및 두피유목은 스타일 및 트렌드관련, 탈모 및 모발관리관련, 헤어제품관련, 광고성의 하위영역 으로 분류하였다. 또한 몸매관리유목은 피트니스관련과 다이어트 관련의 하위영역으로 분류하였다. 분석유목의 선정과 하위 유목의 구체적인 내용은 교수 및 해당 전공 대학원생의 내용 타당도 검토를 거쳐 선정되었으며 기사 의 주제 분류유목과 각 하위영역의 구체적인 내용은 다음 <표 1>과 같다.

\section{3. 자료분석}

본 연구는 수집된 자료를 총 기사건수와 각 분석유목 및 해당 하위영역에 해당하는 기사건수로 나누어 빈도를 측정하였으며, 2000년대로 들어서면서 남성에 대한 인식 이 변화하고 이에 패션 및 뷰티관련 제품이 증가하여서 1996년부터 2005년까지의 시기를 5년 단위로 나누어 각 시기에 대한 해당 기사의 빈도를 측정하였다. 또한 분석 유목별 각 하위영역의 기사내용에 대한 질적인 내용분석 을 실시하였다.

\section{IV. 결과 및 분석}

\section{1. 기사의 유목별 빈도 분석}

1996년부터 2005년까지 에스콰이어에 게재된 전체 기 사의 건수는 총 6147 건이었으며, 그 중 외모관련 기사는 총 2745건이 수집되어 전체 기사에서 외모관련 기사가 차 지하는 비율은 $44.7 \%$ 를 나타냈다. 외모관련 기사를 분석 유목별로 분류한 결과 다음 <표 2>와 같이 가장 높은 빈 도를 보인 것은 패션유목으로 2039건이 수집되어 전체에 서 $74.2 \%$ 의 비율을 나타냈으며, 두 번째로 높은 빈도를 보인 것은 피부 및 화장품유목으로 413건이 수집되어 $15.0 \%$ 의 비율을 보였다.

이와 같은 결과는 다른 매체에 비해 시각적인 면이 차 지하는 비율이 높은 잡지의 특성에 따라 나타난 결과라

<표 2> 잡지기사의 유목별 빈도

$(\mathrm{N}=2747)$

\begin{tabular}{l|l|l}
\hline \multicolumn{1}{c|}{ 분석유목 } & \multicolumn{1}{c}{ 빈도 $(\mathrm{N})$} & \multicolumn{1}{c}{ 백분율 $(\%)$} \\
\hline 패션 & 2039 & 74.2 \\
\hline 피부 및 화장품 & 413 & 15.0 \\
\hline 헤어 및 두피 & 101 & 3.7 \\
\hline 신체이미지 & 94 & 3.4 \\
\hline 성형 & 14 & 0.5 \\
\hline 기타 & 84 & 3.1 \\
\hline 합계 & 2745 & 100 \\
\hline
\end{tabular}

<표 1> 기사의 분류유목 및 하위영역

\begin{tabular}{|c|c|c|}
\hline 영역 & 하위영역 & 세부내용 \\
\hline \multirow{6}{*}{ 패션 } & 트렌드 관련 & 의복 및 액세서리를 포함한 의복 트렌드 소개 \\
\hline & 코디네이션 및 연출방법관련 & 코디네이션 방법 및 아이템별 연출방법 소개 \\
\hline & 액세서리관련 & 남성관련 액세서리 소개 (넥타이, 만년필 등 포함) \\
\hline & 패션화보 & 계절별, 테마별로 패션을 주제로 한 화보 \\
\hline & 광고성 & 브랜드별 신상품이나 시즌별 컬렉션 소개 \\
\hline & 기타 & $\begin{array}{l}\text { 브랜드 및 디자이너스토리, 아이템별 역사소개, Q\&A 코너, 패션에 관련된 } \\
\text { 전체 트렌드 소개 등 }\end{array}$ \\
\hline \multirow{5}{*}{ 화장품 및 피부 } & 케어 및 화이트닝관련 & 얼굴을 위주의 케어, 세안, 화이트닝 관련 기사 \\
\hline & 태닝 및 향수관련 & 태닝이나 향수와 관련된 기사 \\
\hline & 신체 및 면도관련 & 얼굴을 제외한 손, 발, 스파, 면도 관련 기사 \\
\hline & 광고성 & 신상품 및 이벤트 소개 \\
\hline & 기타 & 브랜드 스페셜 및 제품의 성능 외적인 부분 소개 \\
\hline \multirow{4}{*}{ 헤어 및 두피 } & 스타일 및 트렌드관련 & 얼굴형별, 시즌별 스타일 소개 및 트렌드 소개 \\
\hline & 탈모 및 모발관리 & 탈모, 두피관리, 모발관리 관련 \\
\hline & 헤어제품 & 샴푸, 모발화장품 등 헤어관련 제품 소개 \\
\hline & 광고성 & 헤어 및 두피, 탈모관련 제품 소개 \\
\hline \multirow{2}{*}{ 몸매관리 } & 피트니스 & 부위별 운동법, 요가, 운동기구 등 소개 \\
\hline & 다이어트 & 식사요법 등 운동을 제외한 다이어트방법 소개 \\
\hline & 성형 & 피어싱을 포함한 성형으로 분류되는 방법 소개 \\
\hline & 기타 & 사회트렌드 및 외모트렌드 관련 \\
\hline
\end{tabular}


<표 3> 시기별 외모관련 기사 빈도

$(\mathrm{N}=6147)$

\begin{tabular}{c|c|c|c}
\hline 연도 & $\begin{array}{c}\text { 총 기사 } \\
\text { 건수 }\end{array}$ & $\begin{array}{c}\text { 외모관련 기사 } \\
\text { 건수 }\end{array}$ & 백분율(\%) \\
\hline $1996-2000$ & 3189 & 909 & 28.5 \\
\hline $2001-2005$ & 2958 & 1437 & 48.6 \\
\hline 합계 & 6147 & 2346 & 38.2 \\
\hline
\end{tabular}

할 수 있으며, 특히 패션은 가시적인 효과가 가장 크고 다 른 영역에 비해 남성들의 보편적인 관심도가 높아 관련 기사가 많이 게재되기 때문이라 할 수 있다. 그러나 이는 신문기사의 내용분석 결과와 비슷한 양상을 보인 것으로 외모관리 중 남성에게 있어 가장 높은 비율을 차지하는 것은 패션이라 사료된다.

\section{2. 기사의 시기 및 유목별 빈도분석}

연도에 따른 전체 기사건수 및 광고성 기사를 제외한 외모관련 기사건수의 변화를 살펴보기 위해 5년 단위로 나누어 살펴본 결과는 다음 <표 $3>$ 과 같다. 전체 기사건
수는 1996년부터 2000년까지의 시기가 3189건, 2001년부 터 2005년까지의 시기가 2958건으로 나타나 기사건수는 감소하고 광고 수는 증가되는 양상을 보였다.

그러나 외모관련 기사건수는 오히려 증가하여 전체 기 사에서 외모관련 기사가 차지하는 비율은 더욱 증가한 것 으로 나타났다. 최근 들어 사회전반에 걸쳐 메트로섹슈얼 이나 위버섹슈얼 등과 같은 문화현상이 유행하고, 다양한 취향이 공존하면서 잡지의 기사편성에 영향을 준 것이라 생각된다.

외모관련 기사를 5 년 단위로 나누어 각 분석유목과 하 위영역에 따라 분류하여 그 변화양상을 살펴본 결과 다음 <표 4>, <표 5>와 같이 나타났다.

패션유목의 경우에는 1996년부터 2000년까지의 시기보 다 2001년부터 2005년까지의 기사건수가 증가한 것으로 나타났으며, 외모관련 기사에서 차지하는 비율도 증가하 는 것으로 나타나 패션에 대한 남성들의 관심은 시기에 상관없이 지속되어 온 것으로 나타났다.

피부 및 화장품유목의 경우에는 1996년부터 2000년까 지의 시기보다 2001년부터 2005년까지의 기사건수는 증가 하였으나 외모관련 기사에서 차지하는 비율은 소폭이지만

<표 4>연도에 따른 분석유목별 기사 빈도

$(\mathrm{N}=2745)$

\begin{tabular}{|c|c|c|c|c|c|c|c|c|c|c|c|}
\hline $\begin{array}{l}\text { 분석 } \\
\text { 유목 }\end{array}$ & 하위영역 연도 & 1996 & 1997 & 1998 & 1999 & 2000 & 2001 & 2002 & 2003 & 2004 & 2005 \\
\hline \multirow{7}{*}{ 패션 } & 1.트렌드 & 20 & 21 & 13 & 16 & 33 & 27 & 47 & 45 & 49 & 47 \\
\hline & 2.코디네이션 & 23 & 36 & 51 & 40 & 36 & 32 & 41 & 49 & 20 & 40 \\
\hline & 3.액세서리 & 22 & 20 & 28 & 23 & 33 & 39 & 47 & 56 & 41 & 46 \\
\hline & 4.패션화보 & 37 & 22 & 20 & 29 & 34 & 38 & 51 & 61 & 62 & 57 \\
\hline & 5.광고 & 0 & 11 & 2 & 19 & 30 & 24 & 22 & 21 & 43 & 83 \\
\hline & 6.기타 & 25 & 26 & 33 & 28 & 17 & 29 & 18 & 28 & 69 & 59 \\
\hline & 합계 & 127 & 136 & 147 & 155 & 183 & 189 & 226 & 260 & 284 & 332 \\
\hline \multirow{6}{*}{$\begin{array}{l}\text { 피부 및 } \\
\text { 화장품 }\end{array}$} & 1.케어 및 화이트닝 & 3 & 7 & 14 & 13 & 6 & 7 & 21 & 22 & 24 & 28 \\
\hline & 2.태닝 및 향수 & 4 & 3 & 6 & 5 & 6 & 2 & 6 & 6 & 5 & 3 \\
\hline & 3.얼굴이외의 바디 및 쉐이빙 & 2 & 7 & 5 & 5 & 5 & 6 & 12 & 10 & 4 & 5 \\
\hline & 4.광고 & 4 & 17 & 13 & 12 & 20 & 12 & 22 & 12 & 12 & 17 \\
\hline & 5.기타 & 0 & 1 & 1 & 1 & 2 & 0 & 4 & 5 & 3 & 3 \\
\hline & 합계 & 13 & 35 & 39 & 36 & 39 & 27 & 65 & 55 & 48 & 56 \\
\hline \multirow{5}{*}{$\begin{array}{l}\text { 헤어 및 } \\
\text { 두피 }\end{array}$} & 1.스타일의 경향 & 2 & 7 & 6 & 2 & 2 & 1 & 4 & 4 & 2 & 3 \\
\hline & 2.모발관리 & 1 & 1 & 2 & 4 & 1 & 3 & 11 & 7 & 3 & 9 \\
\hline & 3.헤어제품 & 2 & 1 & 0 & 0 & 0 & 1 & 4 & 1 & 1 & 2 \\
\hline & 4.광고 & 0 & 0 & 1 & 0 & 2 & 3 & 4 & 0 & 3 & 1 \\
\hline & 합계 & 5 & 9 & 9 & 6 & 5 & 8 & 23 & 12 & 9 & 15 \\
\hline \multirow{3}{*}{$\begin{array}{l}\text { 신체 } \\
\text { 이미지 }\end{array}$} & 피트니스 & 10 & 13 & 15 & 11 & 3 & 2 & 6 & 5 & 2 & 7 \\
\hline & 다이어트 & 2 & 1 & 2 & 2 & 2 & 1 & 3 & 1 & 2 & 4 \\
\hline & 합계 & 12 & 14 & 17 & 13 & 5 & 3 & 9 & 6 & 4 & 11 \\
\hline 성형 & 성형 & 2 & 3 & 0 & 1 & 2 & 3 & 0 & 1 & 1 & 1 \\
\hline 기타 & 사회트렌드 및 외모트렌드 & 4 & 2 & 4 & 7 & 3 & 4 & 7 & 7 & 10 & 36 \\
\hline \multicolumn{2}{|r|}{ 합계 } & 163 & 199 & 213 & 218 & 237 & 234 & 330 & 341 & 356 & 451 \\
\hline
\end{tabular}


<표 5> 시기에 따른 분석유목별 기사 빈도

$(\mathrm{N}=2745)$

\begin{tabular}{|c|c|c|c|c|c|}
\hline \multirow{2}{*}{\multicolumn{2}{|c|}{$\begin{array}{ll}\text { 분석 } & \text { 연도 } \\
\end{array}$}} & \multicolumn{2}{|c|}{$1996-2000$} & \multicolumn{2}{|c|}{$2001-2005$} \\
\hline & & \multirow{2}{*}{$\begin{array}{r}\text { 빈도 } \\
103\end{array}$} & \multirow{2}{*}{$\frac{\text { 백분율 }}{13.8}$} & \multirow{2}{*}{$\frac{\text { 빈도 }}{215}$} & \multirow{2}{*}{$\frac{\text { 백분율 }}{16.7}$} \\
\hline \multirow{7}{*}{ 패션 } & 1.트렌드 & & & & \\
\hline & 2.코디네이션 & 186 & 24.9 & 182 & 14.1 \\
\hline & 3. 액세서리 & 126 & 16.8 & 229 & 17.7 \\
\hline & 4.패션화보 & 142 & 19.0 & 269 & 20.8 \\
\hline & 5.광고 & 62 & 8.3 & 193 & 14.9 \\
\hline & 6.기타 & 129 & 17.2 & 203 & 15.7 \\
\hline & 합계 & 748 & 72.4 & 1291 & 75.4 \\
\hline \multirow{6}{*}{ 피부 및 화장품 } & 1.케어 및 화이트닝 & 43 & 26.5 & 102 & 40.6 \\
\hline & 2.태닝 및 향수 & 24 & 14.8 & 22 & 8.8 \\
\hline & 3.얼굴이외의 바디 및 쉐이빙 & 24 & 14.8 & 37 & 14.7 \\
\hline & 4.광고 & 66 & 40.7 & 75 & 29.9 \\
\hline & 5.기타 & 5 & 3.1 & 15 & 6.0 \\
\hline & 합계 & 162 & 15.7 & 251 & 14.7 \\
\hline \multirow{5}{*}{ 헤어 및 두피 } & 1.스타일의 경향 & 19 & 58.3 & 14 & 20.9 \\
\hline & 2.모발관리 & 9 & 25.0 & 33 & 49.3 \\
\hline & 3. 헤어제품 & 3 & 8.3 & 9 & 13.4 \\
\hline & 4.광고 & 3 & 8.3 & 11 & 16.4 \\
\hline & 합계 & 34 & 3.3 & 67 & 3.9 \\
\hline \multirow{3}{*}{ 신체이미지 } & 피트니스 & 52 & 85.2 & 22 & 66.7 \\
\hline & 다이어트 & 9 & 14.8 & 11 & 33.3 \\
\hline & 합계 & 61 & 5.9 & 33 & 1.9 \\
\hline 성형 & 성형 & 8 & 0.8 & 6 & 0.4 \\
\hline 기타 & 사회트렌드 및 외모트렌드 & 20 & 1.9 & 64 & 3.7 \\
\hline \multicolumn{2}{|r|}{ 합계 } & 1033 & 100 & 1712 & 100 \\
\hline
\end{tabular}

감소한 것으로 나타났으며, 반면 헤어 및 두피유목은 기 사건수가 증가하면서 외모관련 기사에서 차지하는 비율 또한 소폭 증가한 것으로 나타났다. 전체 외모관련 기사 건수가 증가한 가운데 신체이미지유목과 성형유목은 기사 의 건수가 감소하면서 전체 외모관련 기사에서 차지하는 비율도 감소한 것으로 나타났다.

이와 같은 결과는 읽는 것보다 보는 것, 감각적인 것을 선호하는 경향이 사회 전반적으로 확산되면서 잡지도 시 각적인 측면을 강조하게 되어 나타난 결과라 할 수 있다.

신체이미지의 경우, 부위별 운동방법이나 식이요법 등 은 시대에 따라 크게 변화되지 않는 분야이기 때문에 1996년부터 2000년까지의 시기에 꾸준히 다루어지다가 2001년 이후가 되면서 관련기사가 자연스럽게 감소하게 된 것으로 사료된다.

\section{3. 기사 유목의 하위영역별 변화양상}

분석유목 중 높은 비율을 차지하는 패션유목과 피부 및 화장품유목의 연도별 변화추이를 살펴본 결과 패션유 목은 [그림 1]과 같이 광고영역의 기사건수가 시대의 변화
에 따라 지속적으로 증가하였다. 이는 잡지의 기사형식이 광고성 기사의 증가로 변화되었고, 각 브랜드에서 시즌별 제품트렌드 제시와 함께 신제품을 소개함으로써 광고효과 를 의도하기 때문이라 할 수 있다. 트렌드영역과 액세서 리영역은 큰 폭의 변화 없이 꾸준히 게재되어온 것으로 나타났다. 이는 각 브랜드마다 시즌별로 의복, 액세서리, 소품을 동시에 출시하면서 그에 관련된 기사가 게재되기 때문이라 생각된다.

그러나 코디네이션영역의 기사건수는 2000년 이후로 패션관련 기사에서 차지하는 비율이 점점 감소하고 있는 것으로 나타났다. 이는 믹스\&매치 스타일이나 크로스 오 버 코디네이션의 방법이 증가됨에 따라 법칙과 같이 이루 어져오던 코디네이션이나 연출방법이 다양화, 개성화되면 서 나타난 결과라 할 수 있다.

피부 및 화장품유목은 [그림 2]와 같이 케어 및 화이트 닝영역의 기사가 전 시기에 걸쳐 대부분 높은 비율을 차 지하고 있는 가운데 특히 2002년 이후에는 화장품의 다양 화, 기능화, 세분화가 이루어지면서 기사건수도 급격히 증 가하는 양상을 보였다. 케어제품과 함께 향수도 꾸준히 신상품이 출시되는 화장품의 특성상 광고영역의 기사는 


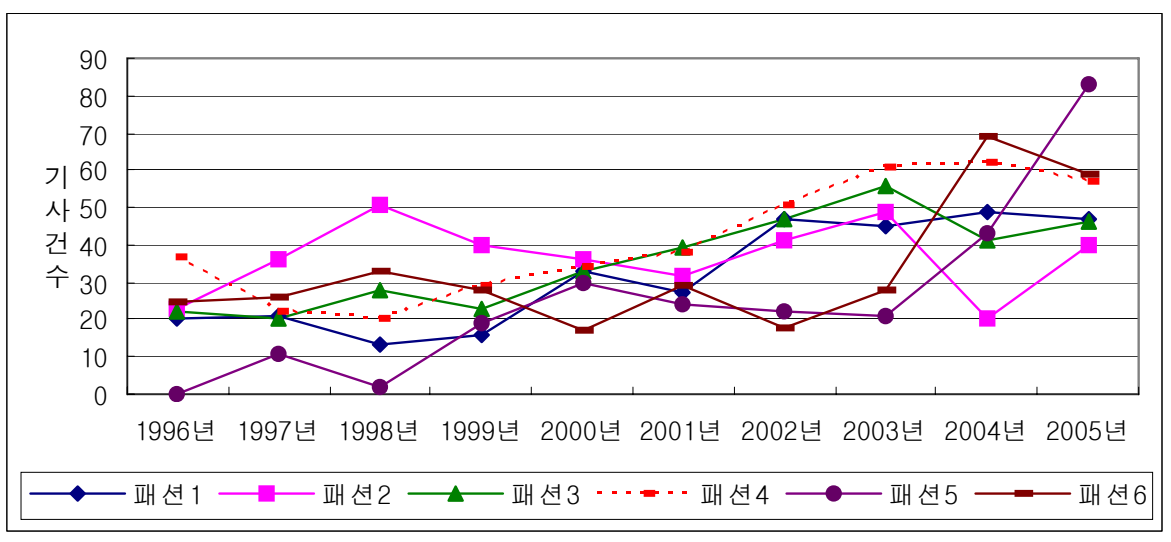

[그림 1] 연도별 패션관련유목 시계열 분석

1.트랜드 2.코디네이션 3.액세서리 4.패션화보 5.광고 6.기타

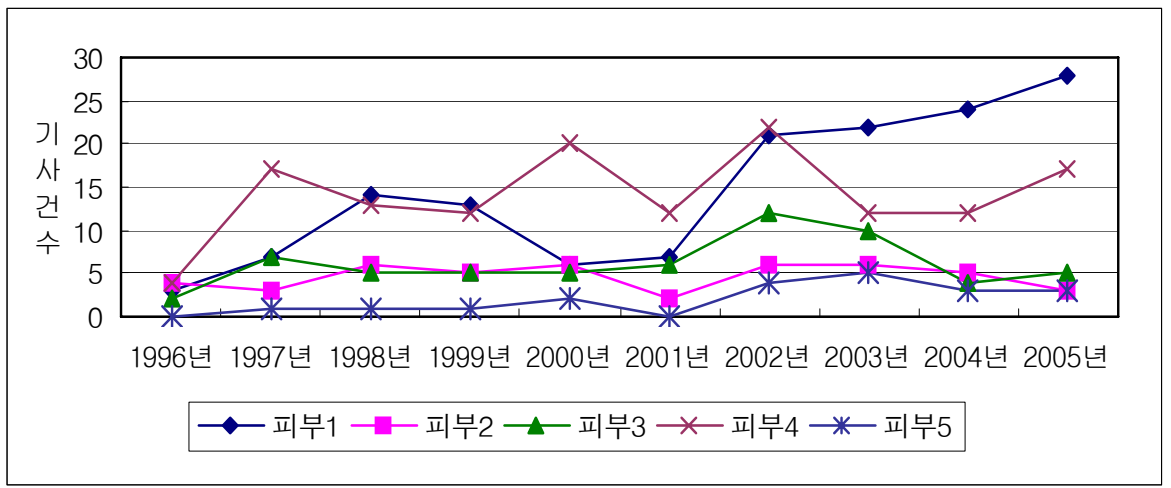

[그림 2] 연도별 피부 및 화장품유목 시계열 분석

1.케어및미백 2.태닝및향수 3.body및shave 4.광고 5. 기타

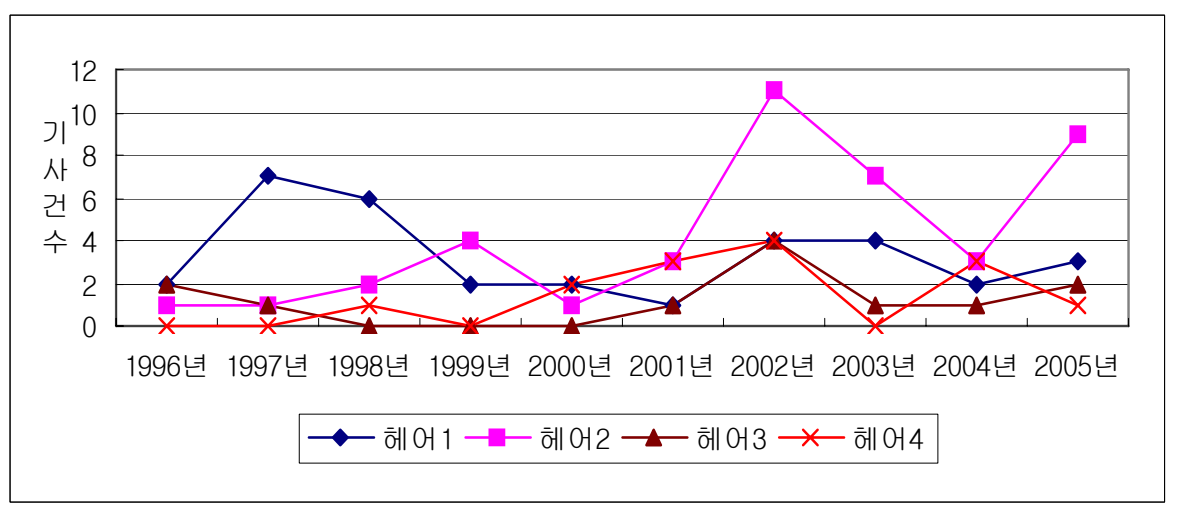

[그림 3] 연도별 헤어 및 두피유목 시계열 분석

1. 트렌드 2.모발관리 3.헤어제품 4.광고

전 시기에 걸쳐 대체적으로 높은 비율을 나타냈으며, 얼 굴을 제외한 바디 및 쉐이빙영역의 기사 건수 또한 꾸준 히 게재되는 것으로 나타났다.

헤어 및 두피유목은 [그림 3]과 같이 1996년부터 2000
년까지와 2001년부터 2005년까지의 시기로 나누어 살펴본 결과 1996년부터 2000년까지의 시기에는 스타일의 경향영 역의 기사가 더 높은 비율을 보였으나, 2001년부터 2005 년까지의 시기에는 모발관리영역의 비율이 더 높아진 것 
으로 나타났다. 이와 같은 결과는 유전적 요인의 영향으 로 여성보다는 남성이 탈모에 대한 고민하는 경우가 빈번 하며, 시대가 변화할수록 환경오염이 심화되고, 남성도 염 색이나 펌을 자주 시술하면서 두피나 모발에 대한 관심이 증가되었기 때문이라 생각된다.

\section{4. 기사의 연도별 내용분석}

1996년부터 2005년까지 에스콰이어에 실린 외모관련 기사를 1996년부터 2000년까지와 2001년부터 2005년까지 의 시기로 나누어 그 내용을 질적으로 내용분석한 결과 외모관련 기사내용의 전체적인 흐름이 1996년부터 2000년 까지는 정보적인 성격을 띤 내용이나 실생활에 적용될 수 있는 실질적인 내용의 기사가 높은 비율을 차지하면서 부 각되었으나, 2001년부터 2005년까지의 시기에는 시각적인 면이 강조되고, 아이템별로 세분화된 내용을 다루는 경향 을 보였다.

연도에 따른 각 유목별 기사내용의 변화를 살펴본 결과 패션유목 중 코디네이션영역은 코디네이션이나 연출방법 의 내용이나 형식에서 차이를 나타내었다. 1996년부터 2000 년까지는 체형별, 스타일별로 코디네이션 방법을 제시하거 나 알뜰 코디 전략 등이 주를 이루는 반면, 2001년부터 2005년까지의 시기에는 계절이나 아이템에 따른 코디네이 션 방법을 제시하거나 재질이나 무늬에 따른 연출방법을 제시하고 있어 세분화, 다양화되는 경향을 나타냈다.

액세서리영역은 그 종류가 증가하였으며, 단일품목으로 소개되던 액세서리가 의복스타일 또는 색상 및 액세서리 간의 조화에 따라 달리 제시되는 등 기사의 형식이 다양 해지는 경향을 보였다.

패션화보영역 또한 외국화보에 의존하던 초기와는 달 리 화보의 비주얼적인 측면에서 질적으로 진보되었을 뿐 아니라 화보의 테마가 다양해지고, 이미지만을 부각시킨 화보가 증가되는 경향을 보였다.

광고영역은 광고성 기사건수가 증가하는 가운데 액세 서리와 관련된 광고성 기사가 의복과 관련된 광고성 기사 보다 더 높은 비율을 보였다. 그러나 이는 국내외 각 브랜 드에서 의복과 함께 신발, 가방, 벨트, 넥타이, 선글라스 등 다양한 액세서리를 동시에 출시하고 있어 의복보다는 액세서리 분야에 더 치중하는 경향을 보인 것이라 생각된 다. 또한 의복과 액세서리의 명확한 구분이 어려운 경우 도 있었다.

피부 및 화장품유목 중 케어 및 화이트닝영역은 두 시 기 모두 보습, 자외선차단, 각질제거, 세안제 등 사용목적 및 제품별로 나누어 피부관리의 필요성과 제품을 소개하
는 형식을 보이고 있었는데 1996년부터 2000년까지보다 2001년부터 2005년까지의 시기에 게재된 기사들이 기능 및 사용목적 등을 더 세분화한 경향을 보였다. 또한 보습 이나 각질제거와 같은 기본적인 제품들과 더불어 주름방 지나 노화방지와 같은 안티 에이징(anti-aging) 제품, 안티 스트레스(anti-stress) 제품 등이 소개되고 있었으며, 화장 품 성분을 분석하거나 제품이 세분화되면서 화장품을 제 대로 바르고 사용하는 방법에 관련된 기사에서부터 피부 트러블과 관련된 기사 및 메이크업 제품소개까지 기사의 내용이 훨씬 더 포괄적이면서 다양화되는 경향을 보였다.

태닝(tanning) 및 향수영역은 1996년부터 2000년까지보 다 2001년부터 2005년까지의 시기에 태닝을 다루고 있는 기사가 감소하는 경향을 보였는데 이는 꽃미남, 메트로섹 슈얼 등의 유행으로 이상적인 남성상의 변화가 영향을 준 것이라 생각된다. 향수기사도 이전 시기보다 2001년부터 2005년까지의 시기에 감소하는 경향을 보였는데 이는 향 수 자체를 다룬 기사보다는 광고성 기사로 다루어지는 경 우가 더 많아 나타난 현상이라 사료된다.

헤어 및 두피유목은 스타일이나 연출하는 방법, 컬러링 을 소개하는 기사가 주를 이루다가 두피케어나 모발관리 에 관한 내용을 다루는 경향을 보였다. 과거보다는 남성 들의 헤어스타일이 보다 자유로워졌으나 직업이나 상황에 따라 스타일의 제한을 받기 때문에 스타일이나 트렌드를 다루는 기사는 감소하였고, 반면 펌이나 염색을 하는 남 성들이 증가하면서, 두피나 모발관리의 중요성이 대두되 면서 그와 관련된 기사가 증가한 것이라 생각된다.

신체이미지유목은 부위별로 근육을 만드는 방법이나 운동기구 사용하는 방법, 직업이나 상황에 맞는 운동법 등 다양한 운동방법을 소개하는 내용을 다루다가 기사건 수가 감소하면서 요가나 스트레칭 등을 위주로 소개하는 경향을 보였다. 이와 같은 변화는 예쁜 남자가 선호되는 사회적 분위기로 인해 웨이트 트레이닝과 관련된 근육운 동보다는 좀 더 부드러운 운동을 선호하는 경향이 반영된 것이라 생각된다. 또한 야외활동을 즐기는 남성들이 증가 하고, 레포츠나 여행정보를 소개하는 기사가 증가하면서 몸매관리에 관한 기사가 감소하는 양상을 나타낸 것이라 사료된다.

성형유목은 워낙 기사건수가 적어 큰 차이는 보이지 않았으나 1996년부터 2000년까지는 부위별 성형방법 등이 소개되기도 했으나, 2001년부터 2005년까지의 시기에는 라식, 피부박피, 모발이식 등 좀 더 실용적인 성형을 다루 었다. 


\section{$\mathrm{V}$. 결론 및 제언}

본 연구는 남성들의 외모에 대한 관심이 증가하고 남 성들이 외모관련 뷰티산업의 주요한 소비층으로 급부상하 고 있는 현 시점에서 남성들의 외모관리에 대한 사회적 인식 및 그 양상을 살펴보는데 그 목적이 있다. 따라서 성, 연령, 취미 등으로 세분화된 특정 층의 개별적이고 구 체적인 욕구에 대응하여 다양한 유행변화를 대중에게 전 달, 제시하며 트렌드를 알리는데 중요한 역할을 하는 패 션잡지기사를 내용분석 함으로써 남성외모에 사회적 인식 의 변화 및 전반적인 경향을 살펴보았다.

잡지에 나타난 기사의 내용을 분석한 결과 총 6147건 의 기사 중 외모관련 기사는 2747 건으로 $44.7 \%$ 를 나타냈 다. 유목별 기사량에 있어서는 패션, 피부 및 화장품, 헤 어 및 두피, 신체이미지, 성형, 기타 유목 중 패션유목이 전체 외모관련 기사의 $74.2 \%$ (2039건)를 차지하였으며, 피 부 및 화장품유목이 $15.0 \%$ (413건)를 차지하였다. 이와 같 이 에스콰이어에 게재된 외모관련 기사는 패션과 피부 및 화장품유목에 집중되어 있었는데 이는 매 시즌마다 새로 운 제품이 출시되는 분야별 특성이 반영된 것이라 사료된 다. 특히 패션관련 기사가 높은 비중을 차지하는 것은 시 각적인 정보인 화보가 많은 비중을 차지하는 잡지의 특성 이 반영되어 나타난 결과라 생각된다.

각 유목별 기사 내용의 특징을 살펴보면 패션유목의 경우, 브랜드 별로 트렌드를 소개하면서 광고의 효과를 동시에 가지려는 광고성기사가 증가하는 경향이었으며, 피부 및 화장품유목의 경우, 케어 및 화이트닝기사가 전 시기에 걸쳐 높은 비율을 차지하였다. 헤어유목은 스타일 링 기사위주에서 탈모 및 모발관리에 대한 기사가 증가하 는 경향을 보였으며, 신체이미지유목은 주로 부위별 피트 니스법을 소개하고 있었으며, 성형유목은 실용적인 성형 을 위주로 한 경우가 많았다.

시기별 기사량의 변화는 1990년대에서 2000년대로 갈수 록 외모관련 기사가 점점 더 증가하였으며, 패션 및 헤어기사 는 2000년대 이후로 증가하는 양상을 보였으나 피부 및 화장 품, 신체이미지, 성형기사는 감소한 것으로 나타났다.

위에서 살펴본 바와 같이 남성들은 대체적으로 외모에 관심을 가지고 있었으며, 남성의 외모관리에 대해서도 긍 정적으로 바라보는 시각이 보편화되는 경향을 보였다. 과 거와 달리 새로운 스타일이나 코디네이션 방법에 호기심 과 흥미를 가지고 수용하려는 태도를 가지려 하는 경향을 보였으며, 다른 사람의 독특한 스타일도 개성으로 받아들 이는 포용력있는 태도를 가진 남성들이 증가하는 경향을 보였다. 또한 잡지는 전문적인 지적 정보 전달의 특성으
로 남성외모관련 정보를 신속하고 정확하게 전달하고 있 었으며, 레포트나 리서치 형식을 빌어 대중의 관심도와 인식정도를 잘 대변하고 있었다.

따라서, 잡지기사를 통해 살펴본 남성들의 외모관리에 대한 관심과 인식의 변화를 바탕으로 잡지의 특성이라 할 수 있는 시각적 정보인 화보의 형식 및 내용의 변화를 분 석하여 남성 스타일의 변화를 살펴봄으로써 남성들의 구 체적이고 실질적인 변화양상을 밝히고, 그들의 욕구 및 취향에 맞는 마케팅 전략을 세우는 것이 필요할 것이다.

주제어 : 외모관리, 패션잡지

\section{참 고 문 헌}

김선희(2003), 외모에 대한 사회문화적 태도와 외모관리행동 에 대한 연구, 대한가정학회지, 41(5), 99 108

김은주(2001), 여대생의 외모관리행동에 관한 연구, 이화여 자대학교 대학원 석사학위논문.

김현주(2006), 2000년이후 패션잡지의 적응저널리즘에 관한 연구, 연세대학교 언론홍보대학원 석사학위논문.

문지영 - 김정원(2004), 20대 남성의 이미지 추구에 관한 연 구, 한국의류산업학회지, 6(6), 715 722

박지현(2002). 현대 한국사회의 ‘몸관리’유행의 사회학적 의 미. 부산대학교 대학원 석사학위논문.

서정우(1990), 잡지언론의 사명, 잡지발전 세미나 자료집, 한 국잡지협회.

이선영(2001), 해외매체의 국내수용 현황 -라이선스 잡지와 외국 영어매체를 중심으로-, 커뮤니케이션북스

이정춘(1990), 현대사회와 매스미디어. 나남.

이재호(2001), 대중매체와 사회, 도서출판 양지.

이희남(1988), 패션미디어로서의 패션잡지에 대한 고찰, 상 지대 논문집, 9, 99 113

윤을요(1997), 국내 라이선스 패션잡지의 현황과 개선방안에 관한 연구, 국민대학교 대학원 석사학위논문.

염혜정(2000), 일본의 패션잡지에 나타난 스트리트 패션 스 타일-1960년대 1990년대를 중심으로-, 한국의류학 회지, 50(6), $73 \sim 87$

전영표(1997), 출판문화와 잡지 저널리즘, 대광문화사.

정규진(2004), 자기표현과 외모관리행동 및 신체노출 관련연 구, 연세대학교 대학원 석사학위논문.

최지성(2002), 남성의 외모관리에 대한 태도 연구, 연세대학 교 대학원 석사학위논문.

(2007. 11. 23 접수; 2008. 1. 25 채택) 